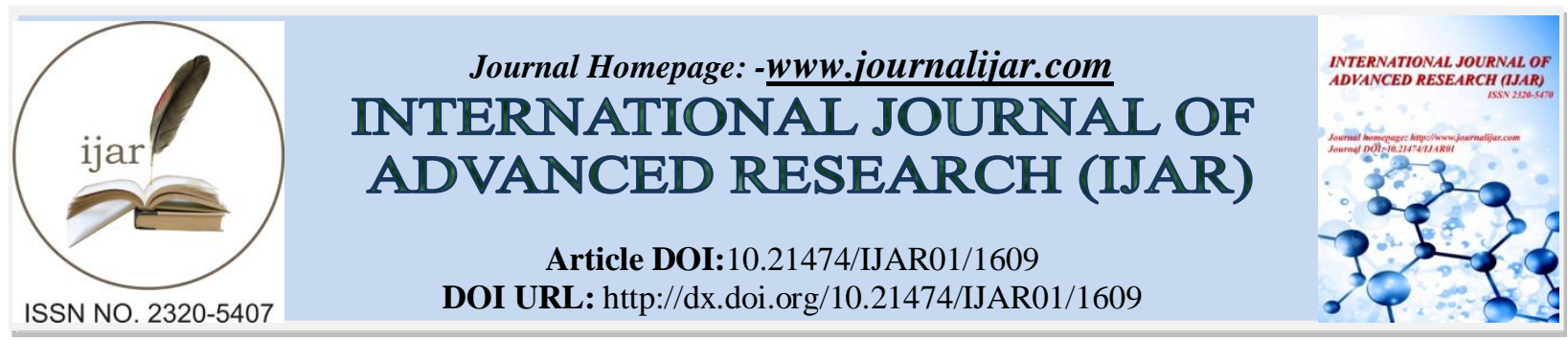

RESEARCH ARTICLE

\title{
SOURCE PARAMETER AND B-VALUE ESTIMATION OF LOCAL EARTHQUAKES IN KUMAUN REGION, CENTRAL HIMALAYA, INDIA.
}

Vivekanand Pathak*, Charu C. Pant, and Santosh Joshi.

Deaprtment of Geology, CAS, Kumaun University, Nainital- 263002, India.

\section{Manuscript Info}

Manuscript History

Received: 12 July 2016

Final Accepted: 23 August 2016

Published: September 2016

Key words:-

Micro-earthquakes, Digital seismic

network, Magnitude, Source parameter,

Shallow focus, b-value.

\section{Abstract}

The earthquake activities recorded by establishing 5 stations digital radio frequency network in Kumaun Himalaya has been used to estimate source parameters and b-value; the network stations were equipped with five short period triaxial (L4-3D) seismometers and one accelerometer (CMG-5T) deployed at Nainital. A majority of microearthquake events attributed between two major tectonic boundaries viz., the Main Boundary Thrust (MBT) in the South and the Main Central Thrust (MCT) in the North shed new light to understanding the nature of seismicity and their relation with regional tectonics of the region. The source parameters viz., seismic moment, source radius and stress drop of local earthquakes have been computed following Brune's earthquake source model (1970). The values of seismic moment $\left(\mathrm{M}_{\mathrm{o}}\right)$, Source radius(r) and stress drop $(\Delta \sigma)$ of micro seismic events vary from $7.52 \mathrm{E}+10(\mathrm{Nm})$ to $4.93 \mathrm{E}+15(\mathrm{Nm})$, from $97 \mathrm{~m}$ to $620 \mathrm{~m}$ and between 0.01 bars to 134 bars, where the stress drop found in agreement with the other region of Himalaya. The focal depths of most of the events are shallow foci in occurrence as well as, the depth of these events ranges from 10-25 km, confining above the plane of detachment. The b-value also estimated for the region to define the relative size distribution of earthquake event falling in the area. It was found to be low as $0.59 \pm 0.11$, interpreted as the region is under the high-stress regime. The spatial distribution of earthquake events between MBT and MCT zones in Kumaun region implies that the region is seismotectonically an active segment of Himalayan fold-andthrust belt.

Copy Right, IJAR, 2016,. All rights reserved.

\section{Introduction:-}

The occurrence of a large number of frequent earthquakes along the Himalayan belt has been identified as Himalayan Seismic belt (HSB) (Kayal, 2001; Gahalaut and Arora, 2012); where most of the seismicity is concentrated between two intracrustalboundary thrusts namely the MBT in the South and MCT in the North. Recent study on global reconstruction and geodetic measurement suggest that the Indian plate converges obliquely towards the Asian plate at a rate of $55-60 \mathrm{~mm} /$ year (DeMets et. al., 1994; Bilham, 1997, 1998), where the convergence is accommodated at a rate of $15-20 \mathrm{~mm} /$ year (Sridevi 2004; Mukul et. al., 2010). As a result, the large amount of internal shear stress is continuously being built up in this region and subsequently followed by the recurrence of frequent earthquake events having small to moderate range of magnitude and sometimes it is large, forming a 
narrow zone between MBT and MCT and making the Himalaya as seimotectonically an active orogen. The Himalaya and adjoining regions had experienced at least four great earthquakes of magnitude $>8.0$ in last ten decades. These includes the Kangra (1905, M. 8.6), Bihar and Nepal (1934, M.8.4), Assam (1950, M.8.5) and Shillong (1987, M.8.7) earthquakes. Besides these three large earthquakes of Uttarkashi (1991, M.6.6),Chamoli (1999, M.6.5) and Muzaffarabad (2005, M. 7.6) have also rocked the region in the recent past and two recently occurred earthquakes of Central Nepal Region, popularly known as Gorkha earthquake or Pokhara earthquake (2015, M. 7.8) and followed by Kodari earthquake (2015, M. 7.2). These historical and recent earthquakes along the Himalayan belt indicate that the entire range is seismically highly active and have a potential for generating a large magnitude earthquake in space and time. Therefore, a part of the seismically active Himalayan region is studied to understand the local seismic scenario and possible impacts to the region.

The present area of investigation includes the region of Kumaun Himalaya of Uttarakhand state, encompassing the Lesser Himalayan Zone. The state of Uttarakhand (Kumaun-Garhwal divisions) lies between two rupture zones of great 1905 (Kangra) and 1934 (Bihar-Nepal) earthquakes and considered as a Central Seismic Gap. Although, two most destructive known and well-documented earthquakes rocked the Garhwal division of Uttarakhand on 20 October 1991 viz., the Uttarkashi earthquake $\left(M_{b} 6.5\right)$ that took toll of 768 lives, caused injuries to 5000 people and damaged 45,765 houses. This earthquake also induced numbers of landslides, ground fissures, and changed hot water chemistry (GSI, 1992). Another well-documented earthquake is 29, March 1999, which is known as the Chamoli earthquake $\left(\mathrm{M}_{\mathrm{s}} 6.6\right)$. The maximum causality and damage occurred in the district of Chamoli, about 106 people died and over 200 injured; about 2,595 houses collapsed and about 10,861 houses were partially damaged. In all, about 1,256 villages were affected (Jain et. al., 1999). The KumaunHimalaya region has no record of such a destructive and great earthquake, although the two moderate earthquakes having magnitude of 6.5 rocked the eastern Kumaun region during 1979 in Seraghat and 1980 in Dharchula. Khattri, (1999) and Pandey, (2002) studied the probabilities of great (characteristic) earthquakes along various sectors of Himalayan Central Seismic Gap. They estimated the return period $\left(\mathrm{T}^{*}\right.$ ) is to be 350 year using a slip rate of $18 \mathrm{~mm} / \mathrm{yr}$ and a slip of $6.2 \mathrm{~m}$ in the last great earthquake. Using the parameters, the 100-yr probability of a great earthquake in this gap is calculated to be 0.52 . They also proposed that the extent of Central Seismic Gap lying between rupture zone of 1905 and 1934 earthquake is very long and has the potential for sustaining two future great earthquakes of the size of 1934 earthquake. It is likely that the possibility of a great earthquake in Kumaun-Garhwal segment is high as Gorkha and Kodari earthquakes have rocked the eastern sector very recently. The geological scenario and tectonic set-up of the Nepal Himalaya and Kumaun-Garhwal Himalaya are very much similar. Therefore, to monitor the seismic activity of the Kumaun Himalaya and adjoining Garhwal region $\left(79^{0} 20^{\prime}-80^{\circ} 36^{\prime} \mathrm{N}\right.$ to $\left.29^{0} 20^{\prime}-30^{\circ} 04^{\prime}{ }^{0} \mathrm{E}\right)$, a seismic network was established in 1999 by Department of science and Technology (DST) and Ministry of Earth Science (MoES), New Delhi, under a sponsored research project by the Centre for Advanced study (CAS) in Geology, Kumaun University. The network lies between two major thrust zones, the MCT in North and MBT in South and monitored the seismicity in between 1999 to 2007. An attempt has been made to find out the source parameter and seismicity pattern of the events occurred in the region. Due to the limitations of the network, the study is more focused on Kumaun Himalaya region.

\section{Geology and Tectonic Setting:-}

The Himalayan fold-and-thrust mountain belt evolved as a consequence of the continent-continent collision between Indian and Asian plates (Gansser, 1964; Seebar and Armbruster, 1981; Ni and Barazangi, 1984). Because of continued northward drifting and underthrusting of Indian landmass beneath the Asia produced large scale crustal shortening, thereby, the crystalline basement got folded and repeatedly split by faulting and thrusting. However, the large-scale crustal shortening was accommodated by south-directed deformation-related tectonic transport of thrust sheets all along the arcuate length of the Himalaya (Gansser, 1964; Molnar and Tapponnier, 1975; Valdiya, 1980; Decelles et. al., 2001). These tectonic thrust sheets are characterized by the major intracrustal boundary thrusts, namely the Himalayan Frontal Thrust (HFT), the Main Boundary Thrust (MBT), the Main Central Thrust (MCT), and the South Tibetan Detachment (STD) from south to north respectively. The Indus Tsangpo Suture Zone (ITSZ) delimits the junction between the two colliding plates namely the Indian Plate and Asian Plate. These deep faults now delimit the boundaries of the geological provinces of the Himalaya and are characterized by unique geological and geomorphologic layout (Fig. 1a).

Valdiya, (1980) has given litho-tectonic setting of the Kumaun-Garhwal region. The Kumaun Himalayan part characterized by the full development of all four litho-tectonic subdivisions of Himalaya, which are separated to each other by the North dipping intracrustal boundary thrusts from South to North respectively (Fig. 1b). The 
Siwalik Group composed of tilted, folded and faulted molasse deposits of Middle Miocene and Pleistocene age are separated from Indo-Gangetic Plane by HFT. The lesser Himalayan unit comprises meta-sediments of Proterozoic ages together with a few outcrop of thrusted older crystalline rock resting over the Siwalik Group along MBT. The Higher Himalaya exposes a massive pile of high-grade metamorphic rock which is complexly faulted and fractured, separated from the Lesser Himalaya by the MCT. The Tethys Himalaya lies over the Higher Himalaya, includes a thick pile of sedimentary rocks of Precambrian to lower Eocene ages and sandwiched between MCT and STD. The Kumaun Himalaya exposes several nappes of metamorphic rocks brought southward over a long distance by imbricate thrusting. The sandwiched part between MBT and MCT in Kumaun Himalaya are characterized by many subsidiary thrusts namely, Berinag Thrust (BT), Ramgarh Thrust (RT), South Almora Thrust (SAT), North Almora Thrust (NAT) and Munsiari Thrust (MT) from south to north respectively. Many faults/thrusts transverse or oblique to those major thrusts that delimit the tectonic boundaries of the region are reactivated during Quaternary time. This is evident by recurrent seismicity, geomorphic developments and by geodetic surveys (Valdiya, 1999; Pant et. al., 2013; Pathak et. al., 2013). The Aravali-Delhi-Haridwar deep-seated structures extending transversely into the Himalaya acting an important role in the tectonics of the Kumaun-Garhwal and adjoining region and probably, it might be cause of complex nature of seismotectonics of the region. The Kumaun Himalaya evolved by an overall southward progression of thrusting, with some reactivation along the Main Boundary thrust (MBT), Munsiari Thrust (MT), and Main Central Thrust (MCT) (Srivastava and Mitra, 1994). In this part, the maximum strain energy is being released in nearby these intracrustal boundary thrusts where most of the seismicity concentrated in the vicinity of MT and MCT. Thus, the state of Uttarakhand is among the most seismically active regions of the Himalayan arc.

\section{Data and Methods:-}

A seismic network of five short period seismic stations, were operated from 1999-2007. Each seismic station was equipped with anL4-3D seismometer and located at Dhaulchhina (DCH), Almora (ALM), Kalakhet (KLT), Kausani (KSN), Nainital (NTL) (Fig. 1b). The central recording Station (CRS) at Nainital was also equipped with aCMG-5T accelerometer. In the telemetered seismic network, the communication link between CRS and Remote Stations were carried out by radio frequency on an allotted frequency bands through the transmitters and receivers. Each remote station had a seismometer vault, 24- bit digitizer, GPS antenna, the battery vault, and a tower equipped with receiver and transmitter with their antennas (Fig. 2). All the equipment were enclosed in a box (see Figure 2, A-F). The L43D seismometers sensed the ground motion at 100 samples per second (SPS) per channel at continuous mode and relayed in real time to the central data acquisition in digital mode with 24-bit resolution and GPS time code receiver having a time accuracy of \pm 5 microseconds. All the stations were located between MBT and MCT and covered many transverse and oblique faults namely, RT, SAT, NAT, and BT. The present data is encompassing the study of 245 microearthquakes having a magnitude range from 0.5 to 5.1, with lowest and acceptable error bars. The data has been used to estimate the hypocentral parameters, source parameters, and b-value.

\section{Source parameter studies:-}

The hypocentral parameters are determined by using the Hypo-71 computer programme developed by Lee and Lahr, (1975), through picking of P and S-wave arrival time at three or more stations (Fig. 3). The analyzed events, so far, indicate a number of low magnitude earthquakes in the Kumaun region. The study of seismic events is the most suitable method to determine the size of earthquake that is directly proportional to the energy released during an earthquake. The epicentral distribution of earthquake events plot on the tectonic map of the region might be helpful in identification of active areas in the vicinity of thrusts and faults of the area (Fig. 4). The P-wave velocity model of Khattriet. al., (1989) has been adopted to determine the hypocentral parameter of the events recorded from 19992007.

Brune, (1970) has given a model to calculate source parameter using near and far-field displacement amplitude spectrum as a function of physical properties at the earthquake source. The source parameters viz., seismic moment $\left(\mathrm{M}_{\mathrm{o}}\right)$, source radius (r) and stress drop $(\Delta \sigma)$ have been estimated from the spectral analysis of P-wave in the vertical component of the displacement spectra using Brune's source model and formulations (Brune, 1970; Sharma and Wason, 1994; Kumar et. al., 2006). These formulations are:

$$
\begin{gathered}
M o=4 \pi \rho v^{3} \mathrm{DAo} / \mathrm{R} \\
\mathrm{r}=2.34 \mathrm{v} / 2 \pi \mathrm{fc} \\
\Delta \sigma=7 \mathrm{Mo} / 16 \mathrm{r}^{3}
\end{gathered}
$$


Where, $\mathrm{M}_{0}, \rho, \mathrm{v}, \mathrm{r}, \mathrm{fc}, \Delta \sigma, \mathrm{D}$, Ao, and R represents seismic moment, density at source $\left(=2.25 \mathrm{~g} / \mathrm{cm}^{3}\right), \mathrm{P}$-wave velocity at source $(=5.2 \mathrm{~km} / \mathrm{s})$, source radius, corner frequency, stress drop, epicentral distance, low frequency level of Pwave and radiation pattern $(=0.85)$ respectively. The above parameters are widely used to determine the source parameters. Since the focal mechanism or the fault-plane solution of individual events could not be calculated because of the few stations and a small aperture of the network. The radiation pattern $\mathrm{R}$ was approximately taken to be $85 \%$ (Sharma and Wason, 1994). The values of the seismic moment $\left(\mathrm{M}_{\mathrm{o}}\right)$, source radius (r) and stress drop $(\Delta \sigma)$ are also calculated for the events from different recording stations and then averaged. In addition to source parameter, the seismic moment defines the energy released during an earthquake, which is proportional to the size of the earthquake as referred by the moment magnitude. The stress drop is the difference of stress before and after an occurrence of an earthquake as calculated by taking an account of $\mathrm{M}_{\mathrm{o}}$ and $\mathrm{r}$.

The values of $\mathrm{M}_{\mathrm{o}}$ plotted against the magnitude $\mathrm{M}_{\mathrm{L}}$ on a semi-log scale (Fig. 5A). Another empirical relationship has also been obtained for the seismic moment against source radius and stress drop (Fig. 5B, 5C). The straight line fits were obtained by least square regression method. The relationships obtained with slopes and intercepts of the straight line fit from the scattered plots. These are as follows:

$\log \left(M_{0}\right)=(0.26 \pm 0.06) M_{L}+(12.37 \pm 0.13)$

$\log (\Delta \sigma)=(0.81 \pm 0.04) \log \left(M_{0}\right)-(10.29 \pm 0.62)$

$\log (\mathbf{r})=(-0.002 \pm 0.01) \log \left(M_{0}\right)+(2.43 \pm 0.14)$

\section{B - value estimation:-}

The frequency - magnitude distribution derives from a power - law relationship between the frequency of earthquake and the magnitude of earth quake by leasts quarefitusing G-R relationship (Gutenberg and Richter, 1956):

\section{$\log N(M)=a-b M$}

Where a-value (Seismic activity) and b-value (Size distribution) are constants to be determined, M isthemagnitude, and $\mathrm{N}(\mathrm{M})$ are the cumulative number of earthquake shaving a magnitude larger than $\mathrm{M}$. The b-value describes the relative size distribution of earthquake events of a given region in a given time period. The máximum likelihood estímate is applied to compute the b-value, which is an appropriate method for acquiring the best estimate of bvalue using the following equation (Utsu, 1965; Aki, 1965).

$$
b=\log (\mathbf{e}) / M-M_{\min }
$$

Where, $\mathrm{M}$ is the mean magnitude and $\mathrm{M}_{\min }$ the mínimum magnitude of the given sample. The simple is considered complete down to the mínimum magnitude $\left(\mathrm{M}_{\min }\right)$. The magnitude of completeness $\left(\mathrm{M}_{\mathrm{c}}\right)$ has to be corrected by $\Delta \mathrm{M} / 2$ to compensate the bias of rounded magnitude to the nearest $\Delta \mathrm{M}$ bin, thus $\mathrm{M}_{\min }=\mathrm{M}_{\mathrm{c}}-\Delta \mathrm{M} / 2$. The magnitude of completeness $\left(\mathrm{M}_{\mathrm{c}}\right)$ is the minimum magnitude in which the catalog is complete. Wiemer and Wyss, (2000) suggest that a careful estimate of the spatial and temporal homogeneity of the magnitude of completeness $\left(\mathrm{M}_{\mathrm{c}}\right)$ isrequired before deviations from a power-law behaviour for small magnitude can be made. Thus, the $\mathrm{M}_{\mathrm{c}}$ is calculated by using the Entire - Magnitude-Range (EMR) method developed by Woessner and Wiemer, (2005). To evaluate the uncertainty or standard deviation of $\mathrm{M}_{\mathrm{c}}$ and b-value, the bootstrap method is employed (Woessner and Wiemer, 2005). In the bootstrap method, the b-value is computed 100 times for each case. Here, we have used $\mathrm{N}=200$ bootstrap simple on a window of 242 earthquakes to evaluate $\mathrm{M}_{\mathrm{c}}$ and $\mathrm{b}$-value for whole Kumaun región along with their standard deviation. Therefore, we have used the EMR method using the Z-map algorithm (Wiemer, 2001) in MATLAB environment, to estímate the magnitude of completeness $\left(\mathrm{M}_{\mathrm{c}}\right)$, a-value and b-value for the seismicity of Kumaun region (Fig. 6).

\section{Results and Discussion:-}

In order to assess the seismicity of the investigated area, we have compiled a total of 245 local micro-earthquake events for the period from 1999 to 2007. From the present database, the epicentral distribution map derived from the analyzed events showing the higher concentration of seismicity lie between MCT and MBT (Fig. 4). This indicates that the region is building stress and released in the form of micro-earthquakes. The GPS derived measurements also indicate that maximum strain accumulation is observed in between MBT and MCT, (Dumka et. al., 2014). The occurrence of earthquakes is confined to a shallow depth (10-25km). Ni and Barazangi, (1984) also reported the 
occurrence of shallow depth $(20 \mathrm{~km})$ earthquake in the Himalayan region. This seismicity is related to the underthrusting process as indicated by the focal mechanism solutions of the earthquake as well as surface geological evidence of northward underthrusting of the Indian plate (Fitch, 1970; Rastogi et. al., 1973; Das and Filson, 1975; $\mathrm{Ni}$ and Barazangi, 1984). Earlier studies on seismicity pattern also indicate that in Garhwal-Kumaun Himalaya, the areas located south of MCT are relatively more active (Khattri, 1999; Kayal, 2001; Thakur and Kumar, 2002; Paul et. al., 2007).The focal depth analysis of the events is carried out with an error bar less than $2.5 \mathrm{~km}$. Most of the events are shallow foci in occurrence where the depth of these events ranges from 10-25 km. The depth distribution of events indicates the majority of earthquake foci confined above the plane of detachment (Fig. 7). The earthquakes reported previously along these regions and all along Himalayan region are of shallow focus in nature. Their depths vary from 13-23 km (Khattri, 1989), 15-20 km (Chandra, 1978; Ni and Barazangi, 1984; Khattri, 1999).

Estimation of source parameter provides important information on assessment of seismic hazard analysis of a region. Several workers (Hanks and Wyss, 1972; Singh et. al., 1979; Hanks and Boore, 1984; Andrews, 1986; Sharma and wasan, 1994; Bansal, 1998; Paul et. al., 2010; Bhat, 2013; Pant et. al., 2013) have made notable contribution in the field of source parameters study following Brune's theory (Brune, 1970), which describes the near and far-field displacement amplitude spectrum as the physical process that releases energy at source. The present study also followed Brune's model for estimation of source parameters of local seismic events. The source parameters of the events, namely, seismic moment $\left(\mathrm{M}_{\mathrm{o}}\right)$, source radius (r) and stress drop $(\Delta \sigma)$ were calculated. The estimated values of the seismic moment $\left(\mathrm{M}_{\mathrm{o}}\right)$, Source radius(r) and stress drop $(\Delta \sigma)$ of micro-earthquake events varies from $7.52 \mathrm{E}+10(\mathrm{Nm})$ to $4.93 \mathrm{E}+15(\mathrm{Nm})$, from $97 \mathrm{~m}$ to $620 \mathrm{~m}$ and between 0.01 bars to 134 bars, where the magnitude $\left(\mathrm{M}_{\mathrm{L}}\right)$ rangesbetween 0.2-5.1.

To interpret the attributes of source parameter, different scatter plots have been made. The plot of source radius of earthquake events with a seismic moment in Figure 5B shows nearly a constant trend, which infers that the source radius is independent of earthquake size in the order of seismic moment for this magnitude range; the plot indicates no significant correlation between seismic moment and source radius. In this study, a linear relationship $\log (\Delta \sigma)=$ $0.81 \log \left(\mathrm{M}_{\mathrm{o}}\right)-10.29$ is estimated from the scatter plot of stress drop against the seismic moment. This plot shows an increasing trend in stress drop with the increase of seismic moment (Fig. 5C). This observation has also been reported by some other workers for micro-earthquake events (Dysart et. al., 1988; Garcia et. al., 1996; Sule, 2010; Parshad et. al., 2014). The most of the events having stress drop value ranging from 0.01 bars to 60 bars whereas only a few events showing stress drop values from upto 80 bars to 134 bars. The stress drop values of the microearthquake events in Kumaun region seems low, which implies that the upper crust of the region has a low strength of stress/strain accumulation and the rocks undergo brittle fracture and adjustments (Paul, 2010). These stress drop values are found in agreement with the other region of the Himalayan arc. An empirical relation $\log \mathrm{M}_{\mathrm{o}}(\mathrm{Nm})=$ $0.26 \mathrm{M}_{\mathrm{L}}+12.37$ has been derived from the seismic moment $\left(\mathrm{M}_{\mathrm{o}}\right)$ and magnitude $\left(\mathrm{M}_{\mathrm{L}}\right)($ Fig. 5A). This relation can be adopted to estimate the moment magnitude $\mathrm{M}_{\mathrm{w}}$ from magnitude $\mathrm{M}_{\mathrm{L}}$ for the magnitude range from 0.2 to 5.1.

The present work also encompasses the computation of $b$-value for the region. The b-value defines the relative size distribution of the earthquake events falling in an area. It is a tectonic parameter to assess the seismic hazard of the tectonically active regions. In a tectonically active region, the b- value is normally close to 1.0 (Frolich and Davis, 1993; Kayal, 2001), this indicates that the number of earthquakes increases 10 fold with magnitude 1.0 unit down. The b-value or the slope of the frequency-magnitude distribution curve depends on stress condition and provides the possibility of stress condition of a region (Mogi, 1962; Scholz, 1968). In contrast to variation in b-value, the value may be influenced by the various factors- increase in material heterogeneity such as the large number of randomly scattered cracks may increase b-value (Mogi, 1962); the spatial and temporal changes in applied shear stress (Scholz, 1968; schorlemmer et. al., 2004; Schorlemmer and wiemer, 2005) or effective stress (Wyss, 1973) may decrease b- value; an increase in thermal gradient may also increase b-value (Warren and Latham, 1970). In this study, the maximum likelihood estimation using EMR method gives the b-value of $0.59(+/-0.11)$ and the a-value of 3.36. The magnitude of completeness is calculated as $\mathrm{M}_{\mathrm{c}}=2.2(+/-0.38)$ corresponding to the linear part of the Gutenberg-Richter (G-R) law for the whole region (Fig. 6). The estimated b-value is to be found low as compared to the normal value. Negi and Paul, (2015) have also reported low b-value for Kumaun region. The low b-value interpreted as the evidence of a relatively high-stress regime (Gibowitz, 1974). Thus, it is anticipated as the region is perpetually buildup stress and not releasing it significantly. 
Figure 1:- Geological map of the study area and the tectonic setting (After Valdiya, 1980).

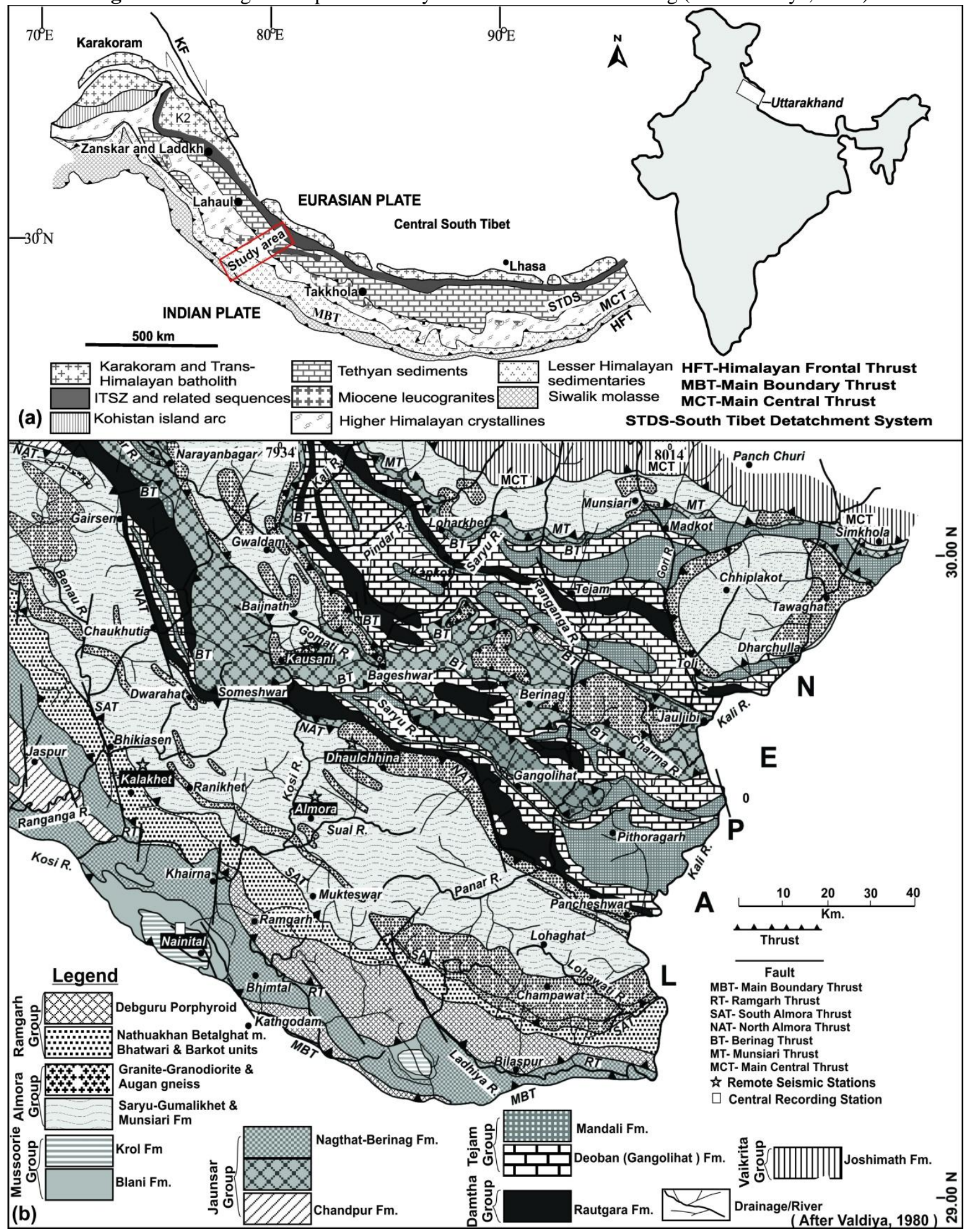


Figure 2:- a-b Remote site setup at DCH and KLT, c- Central Receiving Tower with Yagi and Omni-directional Antenna, d- CRS, view from outside, e- Seismograph and Accelerograph used in the network, f- CRS, inside view.
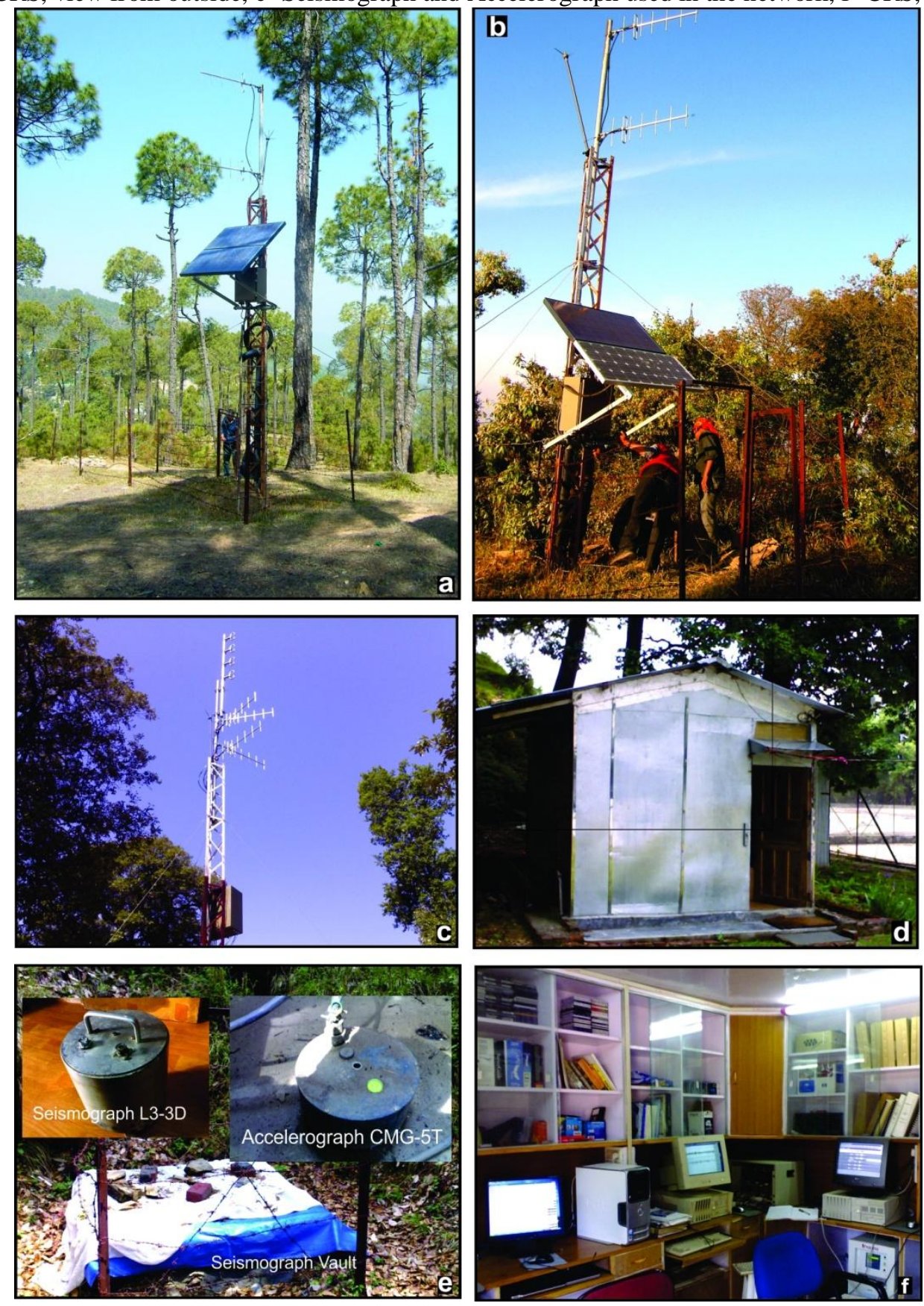
Figure 3:- A waveform window showing phase picking of $\mathrm{P}$ (Primary) and $\mathrm{S}$ (Secondary) arrival time in vertical or $\mathrm{Z}$ and horizontal or $\mathrm{E}$ components.

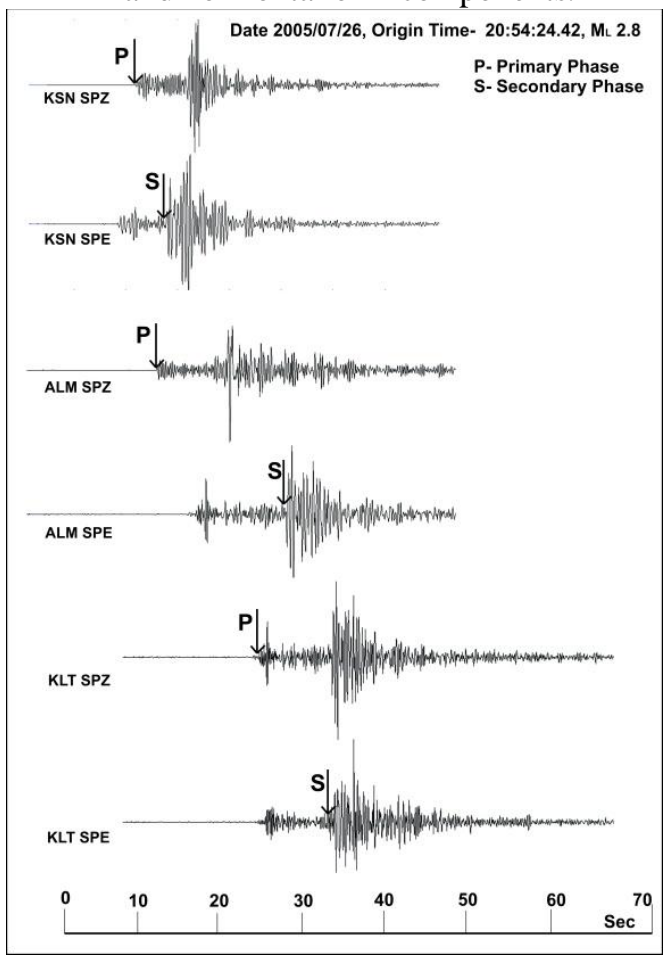

Figure 4:- Spatial distributions of the local micro-earthquake events on the tectonic map of the region.

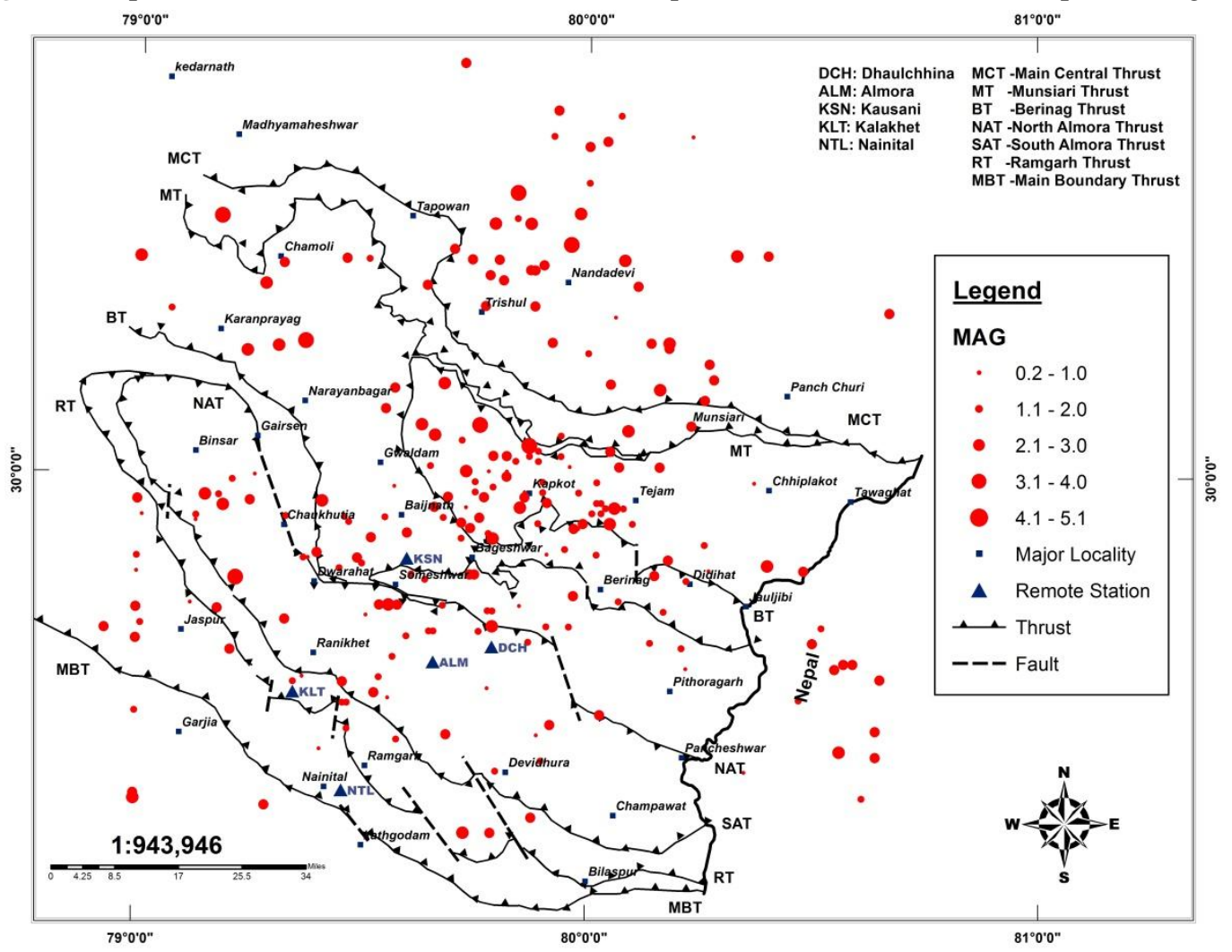


Figure 5:-Empirical relationship of Seismic moment, Source radius and Stress drop and Magnitude where the plots represent the relation between Seismic moment vs. magnitude in plot A, Seismic moment vs. Source radius in plot $\mathrm{B}$, and Seismic moment vs. Stress drop in plot C.
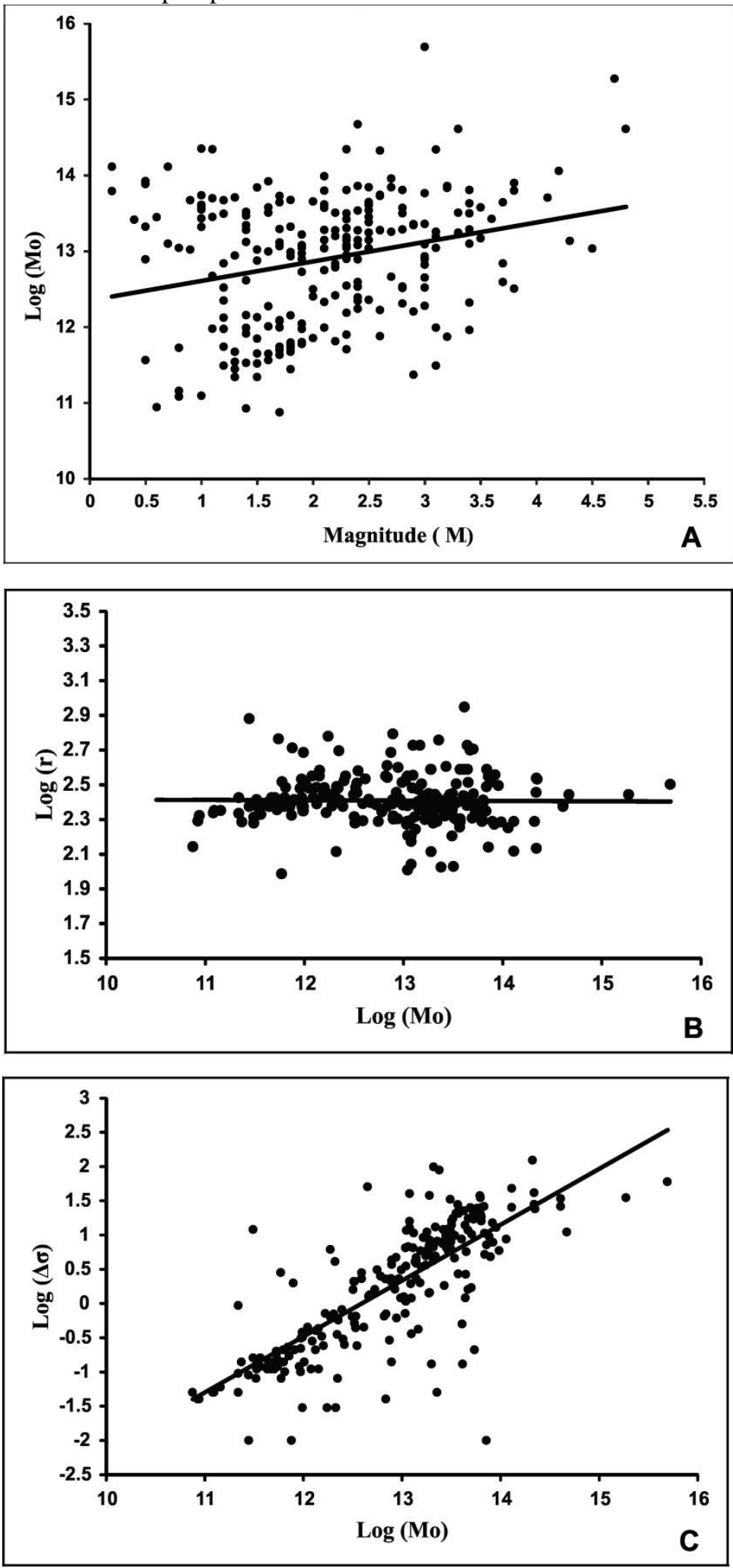
Figure 6:- Cumulative frequency-magnitude distribution for Kumaun region. The inverted triangle indicates the magnitude of completeness $M_{c}$ and the straight line show the goodness of fit for b-value estimation.

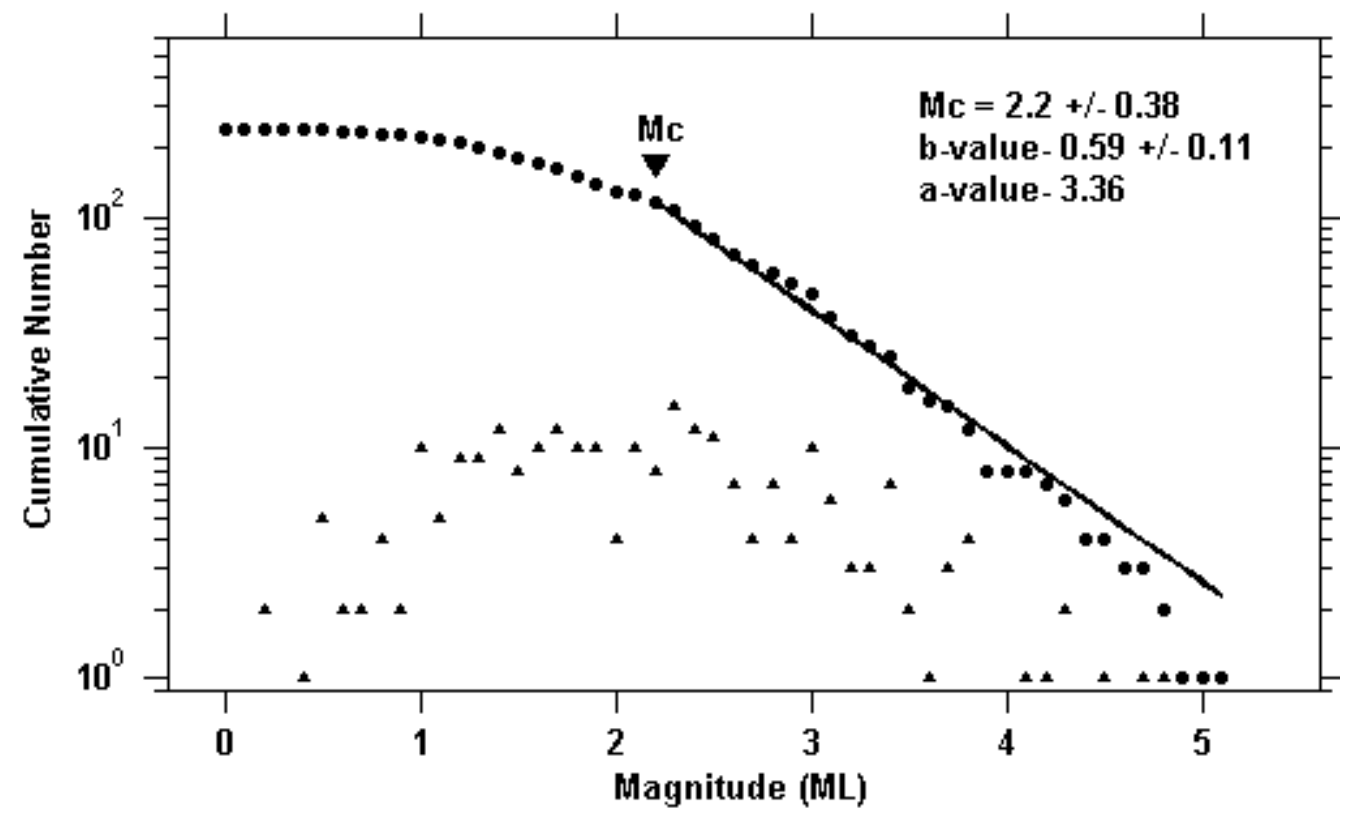

Figure 7:- Focal depth distribution of the earthquake events associated with Thrust/ Faults of the region.

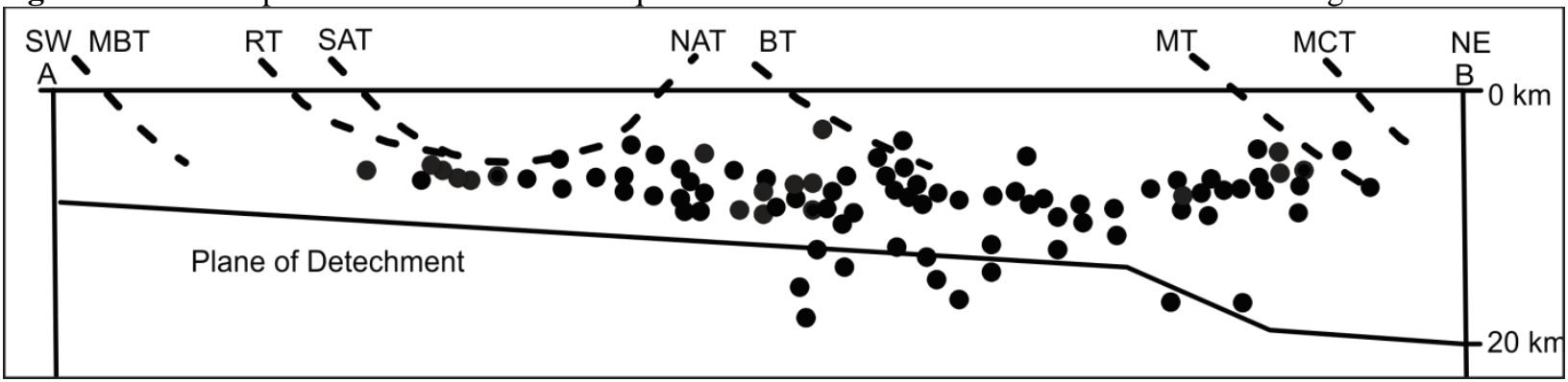

\section{Conclusion:-}

The study of 245 local earthquake events occurred in Kumaun Himalaya shows the variation in source parameter for the magnitude ranging from 0.2-5.1. The variations for seismic moment ranges from $7.52 \mathrm{E}+10(\mathrm{Nm})$ to $4.93 \mathrm{E}+15$ $(\mathrm{Nm})$, for source radius from $97 \mathrm{~m}$ to $620 \mathrm{~m}$, and for the stress drop values in between 0.01 bars to 134 bars where most of the stress drop values falling between a range from 0.01 bars to 60 bars. The average stress drop observed for the Himalayan earthquake is about 60 bars (Kumar et. al., 2008; Kumar, 2011). The stress drop values found to

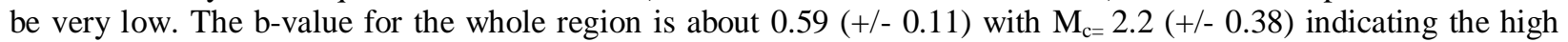
stress condition of the region.

\section{Acknowledgements:-}

The authors express their sincere gratitude to the DST, New Delhi and Ministry of Earth Sciences (MoES), New Delhi for sponsoring the SNKH project. Dr. B.K. Bansal, Advisor and Head Geosciences, MoES, New Delhi, Dr. Ajay Paul, WIHG, Dehradun, Mr. Sanjay S. Negi, WIHG, Dehradun are acknowledged for fruitful discussions and suggestions. We are thankful to the Head, Centre for Advanced Study in Geology, Kumaun University, Nainital for providing the infrastructural facility. 


\section{References:-}

1. Aki, K. (1965). Maximum likelihood estimate of $\mathrm{b}$ in the formula $\mathrm{Log} \mathrm{N}=\mathrm{a}-\mathrm{bM}$ and its confidence limits. Bull. Earthq. Res. Inst. Univ., Tokyo, 43, 237-239.

2. Andrews, D.J. (1986). Objective determination of source parameters and similarity of earthquakes of different size. In Earthquake Source Mechanics, Ewing Series, 6, AGU, 259-267.

3. Bansal, B.K., and Gupta, S. (1998). A glance through the seismicity of Peninsular India. Jour. Geol. Soc. India, 52, 67-80.

4. Bhat, G.M., Pandita, S.K., Singh, Y. and Sharma, S. (2013). Estimation of Source Parameters of Local Earthquakes in Jammu and Kashmir, India. Int. Jour. Sci. and Res. Pub., 3, 2, ISSN 2250-3153.

5. Bilham, R., Blume, F., Bendick, R. and Gaur, V.K. (1998). Geodetic constraints on the translation and deformation of India, implications for future great Himalayan earthquakes. Current Science, 74, 213-229.

6. Bilham, R., Larson, K., Freymueller, J. and Project Idylhim members (1997). GPS measurements of present day convergence across the Nepal Himalaya. Nature, 386: 61-64.

7. Brune, J.N. (1970). Tectonic stress and spectra of seismic shear waves from earthquakes. Jour. Geophys. Res., 75, 4997-5009.

8. Chandra, U. (1978). Seismicity, earthquake mechanisms and tectonics along the Himalayan mountain range and vicinity. Physics of Earth and Planetary Interior, 16, 109-131.

9. Das, S. and Filson, J.R. (1975). On the tectonics of Asia. Earth Planetary Science Letter, 28, 241-253.

10. Decelles, P.G., Robinson, D.M., Quade, J., Ojha, T.P., Garzione, C.N., Copeland, P. and Upreti, B.N. (2001). Stratigraphy, Structure and Tectonic evolution of the Himalayan fold-thrust belt in the western Nepal. Tectonics, 20, 487-509.

11. Demets, C., Gordon, R., Argus, D. and Stein, S. (1994). Effect of recent revisions to the geomagnetic reversal time scale on estimates of current plate motions. Geophys. Res. Lett., 21, 2191-2194.

12. Dumka, R.K., Kotlia, B.S., Kumar, K., Satyal, G.S. and Joshi, L.M. (2014). Crustal Deformation Revealed by GPS in Kumaun Himalaya, India. Journal of Mountain Science, 11, 1, 41-50, DOI: 10.1007/s11629-012-2552$\mathrm{x}$.

13. Dysart, P.S., Snoke, J.A. and Sacks, I.S. (1988). Source parameter and scaling relations for small earthquakes in the Matsushiro region, Southwest Honshu, Japan. Bull. Seismol. Soc. Am., 78, 2, 735-755.

14. Fitch, T.J. (1970). Earthquake mechanisms and tectonics in the Himalayan, Burmese and Andaman regions and continental tectonics in central Asia. Jour. Geophys. Res., 73, 777-784.

15. Frolich, C. and Davis, S. (1993). Teleseismic b-values: or much ado about 1.0. Jour. Geophys. Res., 98, 631644.

16. Gahalaut, V.K. and Arora, B.R. (2012). Segmentation of seismicity along the Himalayan arc due to structural heterogeneities in the underthrusting Indian plate and overriding Himalayan wedge. Episodes, 35, 4, 493-500.

17. Gansser, A. (1964). Geology of the Himalaya. Interscience, New York, USA p. 289.

18. Garcia-Garcia J.M., Vidal, F., Romacho, M.D., Martin-Marfil, J.M., Posadas, A. and Luzon, F. (1996). Seismic source parameters for microearthquakes of the Granada basin (Southern Spain). Tectonophysics, 261, 1, 51-66.

19. Gibowicz, S.J. (1974). Frequency-magnitude, depth and time relations for earthquakes in an island arc: North Island, Newzealand. Tectonophysics, 23, 3, 283-297.

20. Gutenberg, B. and Richter, C.F. (1956). Magnitude and energy of earthquakes. Ann. Geofisica, 9, 1-15.

21. Geol. Surv. Ind. (1992). Uttarkashi Earthquake: October 20, 1991. Special Publication No. 30, Geological Survey of India, Calcutta.

22. Hanks, T.C. and Boore, D.M. (1984). Moment-Magnitude relations in theory and practice. Jour. Geophys. Res., 89, 6229-6235.

23. Hanks, T.C. and Wyss, S.M. (1972). The Use of Body-wave Spectra in the Determination of Seismic-source Parameters. Bull. Seismol. Soc. Am., 62, 561-589.

24. Jain, S.K., Murty, C.V.R., Arlekar, J.N., Rajendran, C.P., Rajendran, K. and Sinha, R. (1999). Chamoli (Himalaya, India) Earthquake of 29 March 1999. EERI Special Earthquake Report, EERI Newsletter, 33, 7.

25. Kayal, J.R. (2001). Microearthquake activity in some parts of the Himalaya and the tectonic model. Tectonophysics, 339, 331-351.

26. Khattri, K.N. (1999). Probabilities of occurrence of great earthquakes in the Himalaya. Proceedings of Indian Academy of Science. Earth and Planetary Science, 108, 2, 87-92

27. Khattri, K.N., Chander, R., Gaur, V.K., Sarkar, I. and Kumar, S. (1989). New seismological results on the tectonics of the Garhwal Himalaya. Proceedings of Indian Academy of Science, Earth and Planetary Science, 98, 91-109. 
28. Kumar, D., Sriram, V. and Khattri, K.N. (2006). A study of source parameters, site amplification functions and average $\mathrm{Q}_{\text {self }}$ from analysis of accelerograms of the 1999 Chamoli earthquake, Himalaya. Pure and Applied Geophysics, 163, 1369-1398.

29. Kumar, D., Sriram, V., Sarkar, I. and Teotia, S.S. (2008). An estimation of a scaling Law of seismic spectrum for earthquakes in Himalaya. Indian Minerals, 61, 3-4 \& 62, 1-4, 83-92.

30. Kumar, A. (2011). Study of earthquake source parameters using micro-earthquakes and strong motion data, Ph.D. Thesis, Indian Institute of Technology, Roorkee.

31. Lee, W.H.K. and Lahr, J.C. (1975). Hypo71 (revised): A computer program for determining hypocenter, magnitude and first motion pattern of local earthquakes. U.S. Geol. Surv. Open-File Rep., 75-311, 1-116.

32. Mogi, K. (1962). Magnitude-frequency relation for elastic shocks accompanying fractures of various materials and some related problem in earthquakes. Bull. Earthq. Res. Inst. Univ. Tokyo, 40, 831-853.

33. Molnar, P. and Trapponnier, P. (1975). Cenozoic tectonics of Asia: Effects of a continental collision. Science, 189, 419-426.

34. Mukul, M., Jade, S., Bhattacharya , A.K. and Bhusan, K. (2010). Crustal shortening in convergent orogens: Insight from Global positioning system (GPS) measurement in northeast India. Jour. Geol. Soc. India, 181, 302-312.

35. Negi, S.S. and Paul, A. (2015). Space-time clustering properties of seismicity in the Garhwal-Kumaun Himalaya, Uttarakhand, India. Himalayan Geology, 36, 1, 91-101.

36. Ni, J. and Barazangi, M. (1984). Seismotectonics of the Himalayan collision zone: the geometry of the underthrusting Indian plate beneath the Himalaya. Jour. Geophys. Res., 89, 1147-1163.

37. Pandey, P. (2002). Seismicity of Uttaranchal. Jour Engineering Geology, Indian Soc. Engineering Geology, XXIX, 89-96.

38. Pant, C.C., Pathak, V. and Darmwal, G.S. (2013). Seismotectonic and neotectonic investigation in a part of 'Central Seismic Gap' Uttarakhand, India. Zeitschrift fur Geomorphologie, 58, 1, 59-79.

39. Parshad, R., R. Rani, S., Ghangas, V., Kumar, R., Rana, V., Joshi, P., Srivastava, P.K. and Ganju, A. (2014). Source parameters of Local earthquakes in Nubra Region, NW Himalaya. International Jour Advanced Research, 2, 8, 151-158.

40. Paul, A. (2010). Evaluation and implications of seismic events in Garhwal-Kumaun region of Himalaya. Jour. Geol. Soc. India, 76, 4, 414-418.

41. Paul, A., Bhakuni, S.S., Pant, C.C., Darmwal, G.S. and Pathak, V. (2010). Microseismicity in Central part of Inner Kumaun Lesser Himalaya: Implications to active seismotectonic. Himalayan Geology, 31, 2, $105-115$.

42. Pathak, V., Pant, C.C. and Darmwal, G.S. (2013). Geomorphological and seismological investigations in a part of western Kumaun Himalaya, Uttarakhand, India. Geomorphology, 193, 81-90.

43. Paul, A., Pant, C.C., Darmwal, G.S. and Pathak, V. (2007). Seismicity of Uttarakhand as recorded by Kumaun Digital Seismic Network. In: "Natural Hazards" Spl. Vol. IGC (eds. O.P. Varma, A.K. Mahajan, and Vikram Gupta), 57-63.

44. Rastogi, B.K., Singh, J. and Verma, R.K. (1973). Earthquake mechanisms and tectonics in the Assam -Burma Region. Tectonophysics, 18, 355-366.

45. Scholz, C.H. (1968). The frequency-magnitude relation of micro-fracturing in rock and its relation to earthquakes. Bull. Seismol. Soc. Am., 58, 399-415.

46. Schorlemmer, D., Weimer, S. and Wyss, M. (2004). Earthquake statistics at Parkfield: 1, Stationarity of b values. Jour. Geophys. Res., 109, B12307, DOI: 10.1029/2004JB003234.

47. Schorlemmer, D. and Weimer, S. (2005). Microseismicity data forecast rupture area. Nature, 434, 1086.

48. Sharma, M.L. and Wason, H.R. (1994). Occurrence of low stress drop earthquake in the Garhwal Himalaya region. Physics of Earth and Planet Interiors, 85, 265-272.

49. Seebar, L. and Armbruster, J.G. (1981). Great detachment earthquakes along the Himalayan arc and long-term forecasting. In: Earthquake prediction: An Int Review, Am. Geophys. Uni., 4, 259-277.

50. Singh, D.D., Rastogi, B.K. and Gupta, H.K. (1979). Spectral analysis of body waves for earthquakes and their source parameters in the Himalaya and nearby regions. Physics of Earth and Planet Interiors, 18, $143-152$.

51. Sridevi, J. (2004). Estimates of plate velocity and crustal deformation in the Indian subcontinent using GPS geodesy. Current Science, 86, 1443-1448.

52. Srivastava, P. and Mitra, G. (1994). Thrust geometry and deep structure of the outer and lesser Himalaya, Kumaun and Garhwal, India: implication for the evolution of the Himalayan fold-and-thrust belt. Tectonics, 13, 89-109.

53. Sule, B. (2010). Spectral source parameters for weak local earthquakes in the Pannonian basin. Central European Journal of Geosciences, 2, 4, 475-480. 
54. Thakur, V.C. and Kumar, S. (2002). Seismotectonic of Chamoli earthquake of March 29, 1999, and earthquake hazard assessment of Garhwal-Kumaun region, NW Himalaya. Himalayan Geology, 23, 113-119.

55. Utsu, T. (1965). A method for determining the value of $\mathrm{b}$ in a formula $\log \mathrm{N}=\mathrm{a}-\mathrm{bM}$ showing the magnitude frequency for earthquakes. Geophys. Bull. Hokkaido Univ., 13, 99-103.

56. Valdiya, K.S. (1980). Geology of the Kumaun Lesser Himalaya, Dehradun, India.Wadia Institute of Himalayan Geology, p. 289.

57. Valdiya, K.S. (1999). Reactivation of faults, active folds and geomorphic rejuvenation in eastern Kumaun Himalaya: wider implication. Indian Journal of Geology, 1-2, 53-63.

58. Warren, N.W. and Latham, G.V. (1970). An experimental study of thermally induced microfracturing and its relation to volcanic seismicity. Jour. Geophys. Res., 75, 4455-4464.

59. Wiemer, S. (2001). A software package to analyze seismicity: Zmap. Seismol. Res. Lett., 72: 373-382.

60. Wiemer, S. and Wyss, M. (2000). Minimum magnitude of completeness in earthquake catalog: an example from Alaska, the Western United State, and Japan. Bull. Seismol. Soc. Am., 90, 4, 859-869.

61. Woessner, J. and Wiemer, S. (2005). Assessing the quality of earthquake catalogues: estimating the magnitude of completeness and its uncertainty. Bull. Seismol. Soc. Am., 95, 2, 684-698.

62. Wyss, M. (1973). Towards a physical understanding of earthquake frequency distribution. Geophys. J. R. Astron Soc., 31, 341-359. 